University of Nebraska - Lincoln

DigitalCommons@University of Nebraska - Lincoln

1990

\title{
Identification of Solubility-Controlling Solid Phases in a Large Fly Ash Field Lysimeter
}

Jonathan S. Fruchter

Pacific Northwest National Laboratory

Dhanpat Rai

Pacific Northwest National Laboratory

John M. Zachara

Pacific Northwest National Laboratory, john.zachara@pnl.gov

Follow this and additional works at: https://digitalcommons.unl.edu/usdoepub

Part of the Bioresource and Agricultural Engineering Commons

Fruchter, Jonathan S.; Rai, Dhanpat; and Zachara, John M., "Identification of Solubility-Controlling Solid Phases in a Large Fly Ash Field Lysimeter" (1990). US Department of Energy Publications. 206.

https://digitalcommons.unl.edu/usdoepub/206

This Article is brought to you for free and open access by the U.S. Department of Energy at DigitalCommons@University of Nebraska - Lincoln. It has been accepted for inclusion in US Department of Energy Publications by an authorized administrator of DigitalCommons@University of Nebraska - Lincoln. 


\title{
Identification of Solubility-Controlling Solid Phases in a Large Fly Ash Field Lysimeter
}

\author{
Jonathan S. Fruchter, * Dhanpat Ral, and John M. Zachara
}

Battelle, Pacific Northwest Laboratories, Battelle Boulevard, Richland, Washington 99352

- Samples of pore fluids and leachates were obtained from a large fly ash field lysimeter in central Pennsylvania. The fly ash in the lysimeter was usually only partially saturated, and only 0.3 pore volumes of water leached through the lysimeter during the 3-year study period. The samples were analyzed for major and trace inorganic anions and cations. The resulting analyses were modeled by using an equilibrium speciation/solubility code to test the hypothesis that the solubilities of at least some species in the fly ash leachate were controlled by solid phases. Potential solubility-controlling solids were identified for $\mathrm{Al}, \mathrm{Ba}, \mathrm{Ca}$, $\mathrm{Cr}, \mathrm{Cu}, \mathrm{Fe}, \mathrm{S}, \mathrm{Si}$, and $\mathrm{Sr}$ in the pore waters and leachates. Solid solutions appear to play an important role in controlling the concentrations of $\mathrm{Ba}, \mathrm{Sr}$, and $\mathrm{Cr}$. The activity relationships were independent of location within the lysimeter and time of sampling. A laboratory experiment showed that equilibration times between these nine elements and their solubility-controlling solids were on the order of days or less. Geochemical reactions controlling the concentrations of As, B, Cd, Mo, and Se were not identified.

\section{Introduction}

The electric utility industry produces approximately 75 million tons of solid waste annually (1). This amount may double by the turn of the century. The vast majority of this waste consists of fly ash and bottom ash produced during the combustion of coal. In the United States, about $80 \%$ of these wastes are disposed of on land, either in landfills or ponds. Both the fly ash and the bottom ash are enriched in certain major and trace elements that have the potential to alter nearby groundwater and surfacewater quality if released in sufficient concentrations. These elements include arsenic, boron, cadmium, chromium, copper, molybdenum, selenium, sulfur, and zinc. It is, therefore, important to understand those chemical processes in the ash/water system that control the concentrations of these elements in the resulting leachate.

A number of recent studies have concentrated on various aspects of fly ash characterization in the laboratory. These have included leaching studies (2-5) and mineralogical and chemical analyses (6-9). Much of this past work has been summarized in a recent review (10). Several of the leaching studies have documented solubility and adsorption phenomena that control leachate composition and have shown that different mineralogical transformations occur with time and environmental exposure.

Published accounts of fly ash leaching under field conditions are limited. In one such study of a midwestern bituminous fly ash pond, six metals ( $\mathrm{Cd}, \mathrm{Cr}, \mathrm{Cu}, \mathrm{Ni}, \mathrm{Pb}$, and $\mathrm{Zn}$ ) were investigated (11). Possible solubility controls were identified for $\mathrm{Cr}, \mathrm{Cu}$, and $\mathrm{Pb}$, including $\mathrm{Cr}(\mathrm{OH})_{3}$, malachite $\left[\mathrm{Cu}_{2}(\mathrm{OH})_{2} \mathrm{CO}_{3}\right]$, and $\mathrm{Pb}(\mathrm{OH})_{2}$. Another study documented the migration of $\mathrm{As}, \mathrm{Cr}, \mathrm{Mo}, \mathrm{Pb}$, and $\mathrm{Se}$ from a lignite fly ash landfill in North Dakota (12). This study found elevated concentrations of all of these elements in groundwaters below the landfill.

This paper reports on the characteristics of pore waters and leachates from a large field lysimeter at the Montour
Power Station, Pennsylvania, under natural rainfall conditions. The lysimeter was well instrumented and equipped with several sampling devices. Aqueous samples were obtained from different depths in the field lysimeter over a 3 -year period starting in 1985, with the objectives of (1) identifying geochemical reactions controlling pore-water concentration over the study period, (2) determining whether laboratory-derived data were applicable to a field situation, and (3) identifying inadequacies in current understanding of the leaching process and in current descriptive thermodynamic constants for the solubility reactions that were postulated to occur.

A previous study (13) has described leachate concentrations and trends from this lysimeter.

\section{Site Description}

The Montour field lysimeter, located in central Pennsylvania, was designed to model a dry coal fly ash disposal facility (14). It was constructed aboveground in the shape of a truncated pyramid, with a $30.5 \mathrm{~m} \times 30.5 \mathrm{~m}$ base and an $18.3 \mathrm{~m} \times 18.3 \mathrm{~m}$ top. The $3.05-\mathrm{m}$-high lysimeter was constructed of $100.305-\mathrm{m}$ layers of compacted fly ash. The fly ash was produced by the combustion of bituminous coal mined in western Pennsylvania. The side slopes were 2:1 horizontal to vertical and vegetated. The top was left bare but covered with a $10-\mathrm{cm}$ layer of bottom ash to prevent wind erosion of the fly ash. A 50-cm layer of bottom ash was also placed at the bottom to facilitate drainage. The lysimeter was equipped with a leachate collection system and a pore-water sampling system, described below.

Because the lysimeter was constructed aboveground and is not irrigated, conditions are only partially saturated except after major precipitation events. Leachate is produced during only part of each year, generally from October to May. The cumulative volume of leachate that exited the base of the lysimeter over the 3-year study period amounted to only 0.3 pore volumes. Thus it seems likely that the ash is still largely unweathered, indicating that the data from the lysimeter should be suitable for comparison with data from laboratory studies performed on freshly collected ash.

\section{Water-Sampling Procedures}

Pore-water samples were obtained with ceramic porous cups installed in multiple-instrument installations or nests. In these installations, ceramic porous cups were set into slurried ash to ensure good hydraulic connection between the porous cups and the fly ash at the borehole wall. Samples were taken by first drawing water into the ceramic cups under vacuum and then pressurizing the ceramic cups from the lysimeter surface to force the water out into $1-\mathrm{L}$ polyethylene bottles.

Leachate samples represented lysimeter drainage and were collected directly from a leachate drain located in the southwest corner of the lysimeter. Aliquots of both leachate and pore waters were subsequently sealed in polyethylene vials after appropriate preservation procedures and transferred to the laboratory for analysis. The sam- 
pling procedures are described in greater detail elsewhere (14).

\section{Solid-Sampling Procedures}

Two sets of solid samples were collected. One set consisted of 10 samples from each of the individual lysimeter construction layers that were set aside in 1984 when the test cell was being constructed. These samples were stored in a field-moist condition until they were analyzed.

The second set consisted of samples from three continuous cores collected from the lysimeter in late 1987 after 3 years of exposure. The cores were collected by using a hollow-stem auger with a lined $1.5-\mathrm{m}$ core barrel. Two cores collected fly ash only. The third core collected 3.05 $\mathrm{m}$ of fly ash and $0.45 \mathrm{~m}$ of the bottom ash drainage blanket at the base of the test cell. All of the core segments contained significant moisture but none were saturated. Visual inspection of these cores did not reveal any horizontal stratification of the ash. The $0.76-\mathrm{m}$ core segments were capped immediately after collection, taped, and coated with paraffin wax to prevent gas or moisture exchange during shipping. The cores were shipped by overnight express in core boxes specially constructed to minimize disturbance. The cores were refrigerated in storage.

\section{Laboratory Procedures}

Extraction of Construction-Layer Samples. The 10 construction-layer samples were equilibrated in deionized/distilled water, and the solutions were analyzed for comparison with the compositions of the pore waters. Replicate 100-g samples of each construction-layer composite were placed in 250-mL plastic centrifuge tubes; 100 $\mathrm{g}$ of water was then added. The 1:1 mixtures were rotated on a shaker for $4 \mathrm{~h}$ at $25^{\circ} \mathrm{C}$, after which $\mathrm{pH}$ was measured on the settled suspension over a 15-min time span. The mixtures were returned to the shaker for 1 week at $25^{\circ} \mathrm{C}$ and then were centrifuged at $4812 \mathrm{~g}$ for $30 \mathrm{~min}$. After centrifugation, the $\mathrm{pH}$, Eh and conductivity of the supernatant were measured under air. The supernatant was then filtered through a prewashed $0.1-\mu \mathrm{m}$ filter.

Core Subsampling, and Extraction and Analysis of Pore Waters. The three cores were subsampled in a glovebox under $\mathrm{N}_{2}$ gas within $60 \mathrm{~h}$ of collection. Selected subsamples were taken in each core at depths of 2.5-20, 60-90, 135-165, 210-240, and 277.5-297.5 cm. Additional subsamples were taken in the deeper core at 302.5-312.5 and $312.5-327.5 \mathrm{~cm}$. First, small cores of known volume were removed for determination of bulk density and moisture content. Then the rest of the subsample was homogenized, and two 200-g samples were put in individual $250-\mathrm{mL}$ plastic centrifuge tubes. One of these $200 \mathrm{~g}$ samples was then freeze-dried, and the other was used in extracting pore water, as described below. The remaining core material was archived.

Freon $113(200 \mathrm{~g})$ was added to the samples, which were centrifuged for $4 \mathrm{~h}$ at $4812 \mathrm{~g}$ under $\mathrm{N}_{2}$ atmosphere to displace pore water (15). The displaced water was recovered from the surface of the Freon and its mass recorded.

Analysis of Water Samples. The various types of water samples obtained by the methods described above are summarized in Table I. The samples were analyzed for 23 elements and species by a combination of atomic absorption spectroscopy (AAS), inductively coupled plasma-atomic emission spectroscopy (ICP-AES), ion chromatography (IC), and specific ion electrodes (SIE). Ranges of data for each analyte are shown in Table II. The samples represent various types of samples from various locations within the lysimeter taken over a 3-year
Table I. Summary of Aqueous Samples Used in This Study

\begin{tabular}{|c|c|c|}
\hline sample name & sample type & location \\
\hline $\mathrm{AB}$ & pore water & sampler nest $\mathrm{AB}$ \\
\hline CD & pore water & sampler nest CD \\
\hline composite & pore water & $\begin{array}{c}\text { composite of sampler } \\
\text { nests } A B \text { and } C D\end{array}$ \\
\hline leachate & leachate & $\begin{array}{l}\text { leachate collection } \\
\text { cistern }\end{array}$ \\
\hline $\begin{array}{l}\text { construction } \\
\text { layers }\end{array}$ & $\begin{array}{l}\text { 1:1 fly ash/water } \\
\text { extract }\end{array}$ & $\begin{array}{l}\text { samples of fly ash } \\
\text { layers used in } \\
\text { lysimeter construction }\end{array}$ \\
\hline $\begin{array}{l}\text { extracted pore } \\
\text { fluid }\end{array}$ & $\begin{array}{l}\text { pore water extracted } \\
\text { by immiscible } \\
\text { displacement }\end{array}$ & $\begin{array}{l}\text { fly ash cores taken } \\
\text { from the lysimeter } 3 \\
\text { years after construction }\end{array}$ \\
\hline
\end{tabular}

Table II. Ranges of Concentrations for Montour Lysimeter Aqueous Samples (in mg/L Except $\mathbf{p H})^{a}$

$\begin{array}{lclc}\text { analyte } & \text { range } & \text { analyte } & \text { range } \\ \mathrm{Al} & 0.40-9.8 & \mathrm{~K} & 1.4-740 \\ \mathrm{As} & 0.007-0.78 & \mathrm{Mg} & 0.3-42 \\ \mathrm{~B} & 0.27-31 & \mathrm{Mn} & 0.006-27 \\ \mathrm{Ba} & <0.007-0.27 & \mathrm{Mo} & 0.15-48 \\ \mathrm{CO}_{3}{ }^{2-} & 25-210 & \mathrm{Na} & 0.56-210 \\ \mathrm{Ca} & 72-800 & \mathrm{Se} & <0.004-0.79 \\ \mathrm{Cl} & 1.5-99 & \mathrm{Si} & 0.70-18 \\ \mathrm{Cr} & 0.041-3.2 & \mathrm{SO}_{4}{ }^{2-} & 140-9600 \\ \mathrm{Cd} & <0.004-0.14 & \mathrm{Sr}^{-} & 0.55-11 \\ \mathrm{Cu} & <0.008-0.50 & \mathrm{Zn} & <0.002-24 \\ \mathrm{~F} & 0.08-11 & \mathrm{pH} & 6.14-10.2 \\ \mathrm{Fe} & <0.01-0.56 & & \end{array}$

${ }^{a}$ For 92 samples.

period. Most of the analytes range over at least 2 orders of magnitude in aqueous concentrations.

\section{Geochemical Calculations}

Our first strategy for interpreting the concentration data for the aqueous samples from the lysimeter was to look for evidence of elements whose concentrations appeared to be controlled by solubility reactions. Elements that could not be interpreted in this simple fashion would then be interpreted in terms of adsorption or kinetic controls. To this end, the analytical data defining the chemical composition ( $\mathrm{pH}$, major and minor cations and anions) of each individual sample were input to the geochemical code MINTEQ (16) for the purpose of calculating ionic strength, ion speciation, single ion activity coefficients, single ion activities for aqueous solute species, and ion activity products and saturation indexes for mineral solids. The use of MINTEQ for these purposes as well as other applications is described in two user's manuals $(17,18)$.

\section{Results}

The discussion that follows emphasizes the elements $\mathrm{Al}$, $\mathrm{Ba}, \mathrm{Ca}, \mathrm{Cr}, \mathrm{Cu}, \mathrm{Fe}, \mathrm{S}, \mathrm{Si}$, and $\mathrm{Sr}$, for which the aqueous concentrations can be interpreted or related to specific solubility reactions. Those elements (As, B, Cd, Mo, and Se) for which controlling solubility reactions were not identified are also briefly discussed.

Major Ash Constituents. Aluminum. Measured Al concentrations varied by more than 2 orders of magnitude in the various samples from the large field lysimeter site. Previous laboratory studies (5) implied that in many fly ashes $\mathrm{Al}$ is controlled by the solubility of $\mathrm{Al}(\mathrm{OH}) \mathrm{SO}_{4}$ when $\mathrm{pH}$ values are less than $\sim 6.0$, by amorphous $\mathrm{Al}(\mathrm{OH})_{3}$ when $\mathrm{pH}$ is between $\sim 6.0$ and 9.0 , and by crystalline $\mathrm{Al}(\mathrm{OH})_{3}$ (gibbsite) when $\mathrm{pH}$ is greater than 9.0. Since the $\mathrm{pH}$ of all samples from the field lysimeter was above 6.0 , it was expected that amorphous $\mathrm{Al}(\mathrm{OH})_{3}$ and gibbsite would 


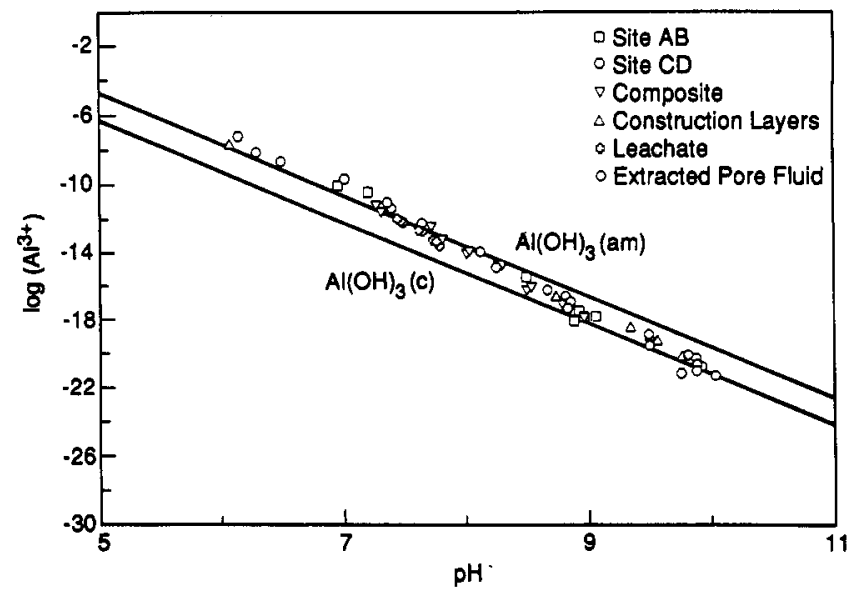

Floure 1. Plot of calculated $\mathrm{Al}^{3+}$ activity vs $\mathrm{pH}$ for various fly ash lysimeter samples, compared to activities predicted (solld lines) from control by crystalline $\mathrm{Al}(\mathrm{OH})_{3}$ (gibbsite) and amorphous $\mathrm{Al}(\mathrm{OH})_{3}$.

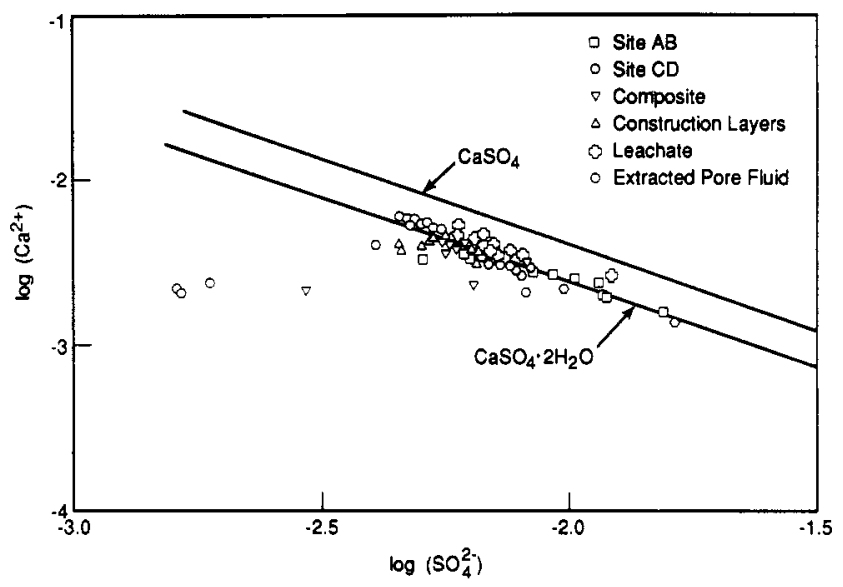

Figure 2. Plot of calculated $\log \mathrm{Ca}^{2+}$ activity vs calculated $\log \mathrm{SO}_{4}{ }^{2-}$ activity for various fly ash lysimeter samples, compared to activities predicted (solld line) from control by $\mathrm{CaSO}_{4}$ (anhydrite) and $\mathrm{CaSO}_{4} \cdot 2 \mathrm{H}_{2} \mathrm{O}$ (gypsum).

control the solubility of $\mathrm{Al}$. The computed $\mathrm{Al}^{3+}$ activities (Figure 1) varied as a smooth function of $\mathrm{pH}$, regardless of the origin of samples. Comparison of the observed $\mathrm{Al}^{3+}$ activities with those predicted to be in equilibrium with the $\mathrm{Al}(\mathrm{OH})_{3}(\mathrm{am})$ and $\mathrm{Al}(\mathrm{OH})_{3}(\mathrm{c})$ (Figure 1) indicated that the activities observed at $\mathrm{pH}$ values of less than $\sim 8.5$ and greater than 9 were similar to those in equilibrium with $\mathrm{Al}(\mathrm{OH})_{3}(\mathrm{am})$ and $\mathrm{Al}(\mathrm{OH})_{3}(\mathrm{c})$, respectively. These results were consistent with the experimental data for fly ashes reported by several authors $(5,19,20)$.

Calcium and Sulfur. $\mathrm{Ca}$ and $\mathrm{S}$ were the major soluble elements in the pore waters and leachates. Analytical measurements showed that reduced $\mathrm{S}$ species $\left(\mathrm{SO}_{3}{ }^{2-}\right.$, $\mathrm{S}_{2} \mathrm{O}_{3}{ }^{2-}$ ) were present in negligible quantities and that $\mathrm{SO}_{4}{ }^{2-}$ was the dominant species. The presence of $\mathrm{SO}_{4}{ }^{2-}$ as the dominant species was consistent with the oxidizing redox potentials and the presence of other highly oxidized aqueous species, such as $\mathrm{CrO}_{4}{ }^{2-}$. Concentrations of $\mathrm{SO}_{4}{ }^{2-}$ were high, with an average concentration of $\sim 0.02 \mathrm{M}$, commensurate with the high S concentrations typically present in bituminous coals and their ashes. Calcium concentrations in fly ashes may be controlled by $\mathrm{CaSO}_{4} / \mathrm{CaSO}_{4} \cdot 2 \mathrm{H}_{2} \mathrm{O}, \mathrm{CaCO}$, or $\mathrm{Ca}(\mathrm{OH})_{2}(10)$. Among these compounds, $\mathrm{Ca}(\mathrm{OH})_{2}$ is expected only at very high $\mathrm{pH}$ values (greater than $\sim 12$ ). Calcium activities were essentially independent of $\mathrm{pH}$ in the measured $\mathrm{pH}$ range (6-10), suggesting that $\mathrm{CaCO}_{3}$ and $\mathrm{Ca}(\mathrm{OH})_{2}$ are not the solubility-controlling solids. The plot of $\mathrm{Ca}^{2+}$ activity as a function of $\mathrm{SO}_{4}{ }^{2-}$ activity (Figure 2) shows that $\mathrm{Ca}^{2+}$

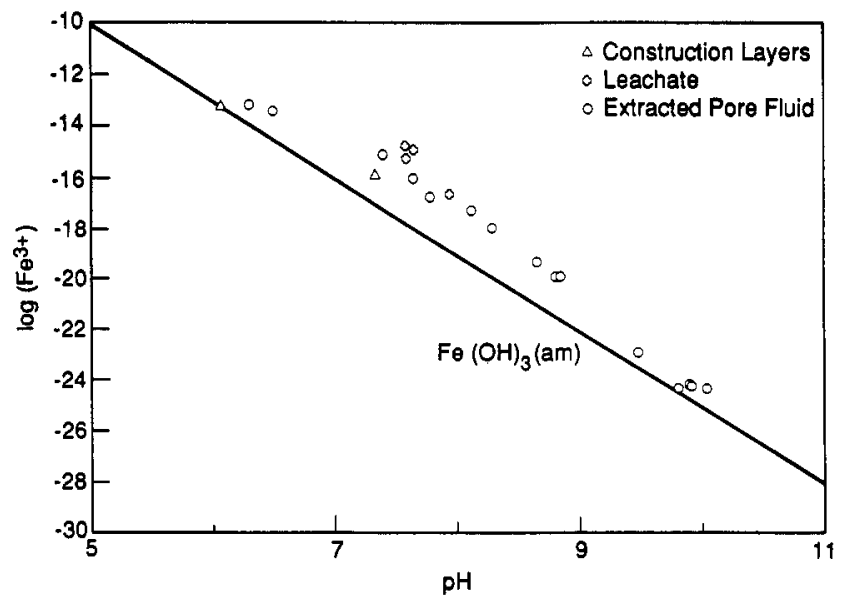

Flgure 3. Plot of calculated $\log \mathrm{Fe}^{3+}$ activity vs pH for various fly ash lysimeter samples, compared to activities predicted (solid line) from control by amorphous $\mathrm{Fe}(\mathrm{OH})_{3}$.

activity decreased as sulfate activity increased, as would be expected if $\mathrm{Ca}$ concentrations were controlled by calcium sulfate. Both $\mathrm{CaSO}_{4}$ and $\mathrm{CaSO}_{4} \cdot 2 \mathrm{H}_{2} \mathrm{O}$ have been identified in fly ashes by many researchers $(6,10,21,22)$. The $\mathrm{Ca}^{2+}$ activities observed were similar to those predicted from $\mathrm{CaSO}_{4} \cdot 2 \mathrm{H}_{2} \mathrm{O}$ (Figure 2). Because $\mathrm{CaSO}_{4} \cdot 2 \mathrm{H}_{2} \mathrm{O}$ (gypsum) rather than $\mathrm{CaSO}_{4}$ (anhydrite) usually precipitates below $42{ }^{\circ} \mathrm{C}$ from aqueous solutions of an ionic strength less than that of seawater (23), this result was expected.

Iron. Aqueous $\mathrm{Fe}$ was present in measurable quantities only in the leachate, construction layers, and extracted pore water; it was below detection limits in all other samples. Speciation measurements made by ion chromatography indicated that all of the detectable $\mathrm{Fe}$ in these samples was in the $\mathrm{Fe}$ (III) state. The similarity of the measured $\mathrm{Fe}^{3+}$ activities to those calculated in equilibrium with $\mathrm{Fe}(\mathrm{OH})_{3}(\mathrm{am})$ (Figure 3) in some of the samples and the reported presence of amorphous $\mathrm{Fe}(\mathrm{OH})_{3}(\mathrm{am})$ in other fly ashes (6) together suggest that $\mathrm{Fe}$ concentrations may be controlled by $\mathrm{Fe}(\mathrm{OH})_{3}(\mathrm{am})$. However, between $\mathrm{pH} 7$ and 9 , the calculated iron activities are almost 2 orders of magnitude higher than those expected from reported values for $\mathrm{Fe}(\mathrm{OH})_{3}(\mathrm{am})$. Possible explanations for this discrepancy are (1) that despite the fact that $0.0030-\mu \mathrm{m}$ filters were used on the construction layer and extracted fluid samples $(0.1 \mu \mathrm{m}$ was used on the leachate sample), some colloidal iron still remained in the filtrates, and (2) that the published thermochemical data for amorphous iron hydroxides are not accurate.

Silicon. Si was one of the major matrix elements of the fly ash. Aqueous Si concentrations were measured in selected samples only (composite pore-water samples, extracted pore water, leachate, and construction-layer samples). The computed aqueous activities of $\mathrm{H}_{4} \mathrm{SiO}_{4}$ (Figure 4) indicated that $\mathrm{SiO}_{2}$ (amorphous or quartz) was not controlling the $\mathrm{Si}$ concentrations in the test-cell pore waters. The similarity of the measured activities to those predicted in equilibrium with wairakite (Figure 5) suggested that wairakite might be the solubility-controlling aluminosilicate. Wairakite $\left(\mathrm{CaAl}_{2} \mathrm{Si}_{4} \mathrm{O}_{12} \cdot 2 \mathrm{H}_{2} \mathrm{O}\right)$ is the $\mathrm{Ca}$ analogue of the more common sodium zeolite, analcite. It has been reported in altered/weathered volcanic tuff. Whether this solid can or will form in utility fly ash is not known at present. Other studies have suggested other aluminosilicates, such as proto-imogolite (6), laumontite (10), or mullite (11).

Minor Ash Constituents. Barium and Strontium. $\mathrm{Ba}$ and $\mathrm{Sr}$ form sparingly soluble compounds with carbo- 


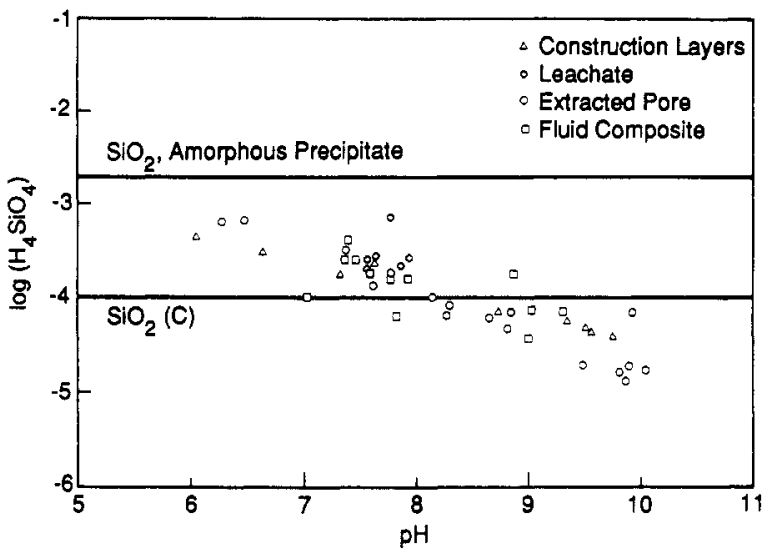

Figure 4. Plot of calculated log $\mathrm{H}_{4} \mathrm{SiO}_{4}$ activity for various fly ash lysimeter samples, compared to activities predicted (solid line) from control by $\mathrm{SiO}_{2}(\mathrm{c})$ (quartz) and amorphous $\mathrm{SiO}_{2}$.

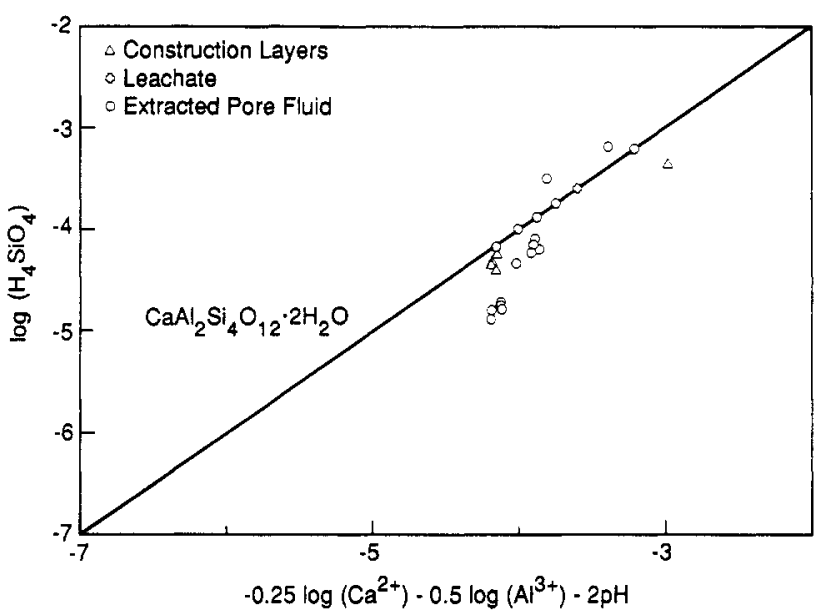

Flgure 5. Plot of $\log \mathrm{H}_{4} \mathrm{SiO}_{4}$ activity of various fily ash lysimeter samples vs the logarithm of the equilibrium expression for the formation of $\mathrm{CaAl}_{2} \mathrm{Si}_{4} \mathrm{O}_{12} \cdot 2 \mathrm{H}_{2} \mathrm{O}$ (wairakite). Only those samples from Figure 4 that had measured $\mathrm{A}^{3+}$ concentrations above the detection limit are included in this figure.

nates and sulfates. The total concentrations of $\mathrm{Ba}$ varied by about an order of magnitude, while those of Sr were nearly constant in the pore waters and leachates. The concentrations of $\mathrm{Ba}$ and $\mathrm{Sr}$ were essentially independent of $\mathrm{pH}$ throughout the measured $\mathrm{pH}$ range, suggesting that $\mathrm{BaCO}_{3}$ and $\mathrm{SrCO}_{3}$ were not the solubility-controlling solids. Because the dominant pore-water anion was $\mathrm{SO}_{4}{ }^{2-}$, the activities of $\mathrm{Ba}^{2+}$ and $\mathrm{Sr}^{2+}$ were plotted as a function of the activity of $\mathrm{SO}_{4}{ }^{2-}$ (Figure 6) to determine if celestite $\left(\mathrm{SrSO}_{4}\right)$ and barite $\left(\mathrm{BaSO}_{4}\right)$ control pore-water concentrations. The results for $\mathrm{Ba}$ showed that $\mathrm{Ba}^{2+}$ activities were up to an order of magnitude higher than those in equilibrium with $\mathrm{BaSO}_{4}$ (c). In addition, the results for $\mathrm{Sr}^{2+}$ in Figure 6 showed that $\mathrm{Sr}^{2+}$ was slightly undersaturated with respect to celestite $\left(\mathrm{SrSO}_{4}\right)$. These results for $\mathrm{Ba}$ and $\mathrm{Sr}$ are similar to those reported for a large number of unweathered fly ashes (5).

Recent experiments in our laboratory with the freshly coprecipitated $(\mathrm{Ba}, \mathrm{Sr}) \mathrm{SO}_{4}$ also showed a similar behavior. This laboratory-observed behavior was found to be not the result of thermodynamic equilibrium with a $(\mathrm{Ba}, \mathrm{Sr}) \mathrm{SO}_{4}$ solid solution, but instead a result of perhaps a stronger interaction between $\mathrm{Ba}$ and $\mathrm{SO}_{4}$ than between $\mathrm{Sr}$ and $\mathrm{SO}_{4}$. In the Ba-substituted $\mathrm{SrSO}_{4}$, this stronger interaction would reduce the solubility of $\mathrm{SrSO}_{4}$, and in Sr-substituted $\mathrm{BaSO}_{4}$, it would increase the solubility of $\mathrm{BaSO}_{4}$. With aging of the coprecipitates, however, the $\mathrm{Ba}$ and $\mathrm{Sr}$ activities were seen to approach that of the pure end mem-
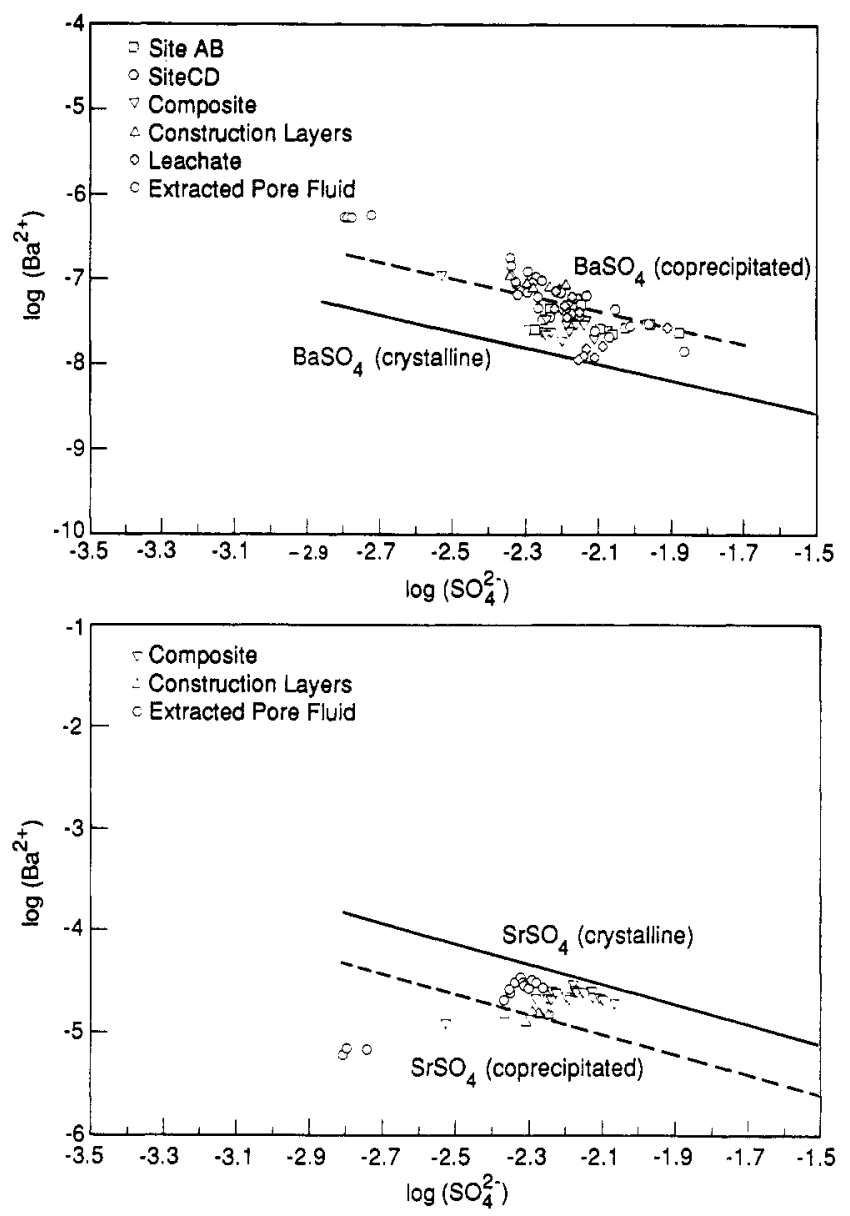

Figure 6. Plots of calculated $\log \mathrm{Ba}^{2+}$ activity and calculated $\log \mathrm{Sr}^{2+}$ activity vs calculated $\log \mathrm{SO}_{4}{ }^{2-}$ activity for various fly ash lysimeter samples, compared to activities predicted (solid lines) from control by $\mathrm{BaSO}_{4}(\mathrm{c})$ (barite) and $\mathrm{SrSO}_{4}(\mathrm{c})$ (celestite).

bers. Total $\mathrm{Ba}$ and $\mathrm{Sr}$ were present in equimolar ratios in the ash. The fact that the observed $\mathrm{Ba}$ and $\mathrm{Sr}$ behavior in lysimeter samples was similar to the 14-day equilibrated-coprecipitated $\left(\mathrm{Ba}_{0.5} \mathrm{Sr}_{0.5}\right) \mathrm{SO}_{4}$ (Figure 6) indicates that the lysimeter fly ash was relatively unweathered. The results collectively show that $\mathrm{Ba}$ and $\mathrm{Sr}$ concentrations are controlled by their sulfate solids, currently more likely by coprecipitated $(\mathrm{Ba}, \mathrm{Sr}) \mathrm{SO}_{4}$ than by $\mathrm{BaSO}_{4}$ or $\mathrm{SrSO}_{4}$.

Chromium. Oxidation-state analyses of the samples showed that the soluble $\mathrm{Cr}$ was present as $\mathrm{Cr}$ (VI). Because of the very high sulfate concentrations and near-neutral to alkaline $\mathrm{pH}$ values, adsorption was not expected to control $\mathrm{Cr}$ concentrations. Studies have shown that $\mathrm{CrO}_{4}{ }^{2-}$ adsorption is significantly depressed in the presence of $\mathrm{SO}_{4}$ (24). It has also been shown that $\mathrm{BaCrO}_{4}$ and $\mathrm{Ba}(\mathrm{S}, \mathrm{Cr}) \mathrm{O}_{4}$ have relatively low solubilities and rapid precipitation/ dissolution kinetics, and that they could form and control $\mathrm{Cr}$ (VI) concentrations in geologic environments (25). These solids may be important in the large field lysimeter, where there are significant total concentrations of $\mathrm{Ba}$ and $\mathrm{SO}_{4}{ }^{2-}$. A comparison of measured $\mathrm{CrO}_{4}{ }^{2-}$ activity with that in equilibrium with $\mathrm{BaCrO}_{4}$ (Figure 7) showed that $\mathrm{BaCrO}$ was not the solubility-controlling solid. The reported results (25) demonstrated that $\mathrm{Ba}(\mathrm{S}, \mathrm{Cr}) \mathrm{O}_{4}$ was more stable than $\mathrm{BaCrO}_{4}$. Additionally, this solid solution was found to control $\mathrm{Cr}(\mathrm{VI})$ levels in an oxidizing $\mathrm{SO}_{4}{ }^{2-}$-containing soil. To evaluate whether $\mathrm{Ba}(\mathrm{S}, \mathrm{Cr}) \mathrm{O}_{4}$ is the solubilitycontrolling solid, the specific composition of the $\mathrm{Ba}(\mathrm{S}, \mathrm{Cr}) \mathrm{O}_{4}$ in the ash must be known. At present, techniques are not available to characterize the small quantities of $\mathrm{Ba}(\mathrm{S}, \mathrm{Cr}) \mathrm{O}_{4}$ in the fly ash. 


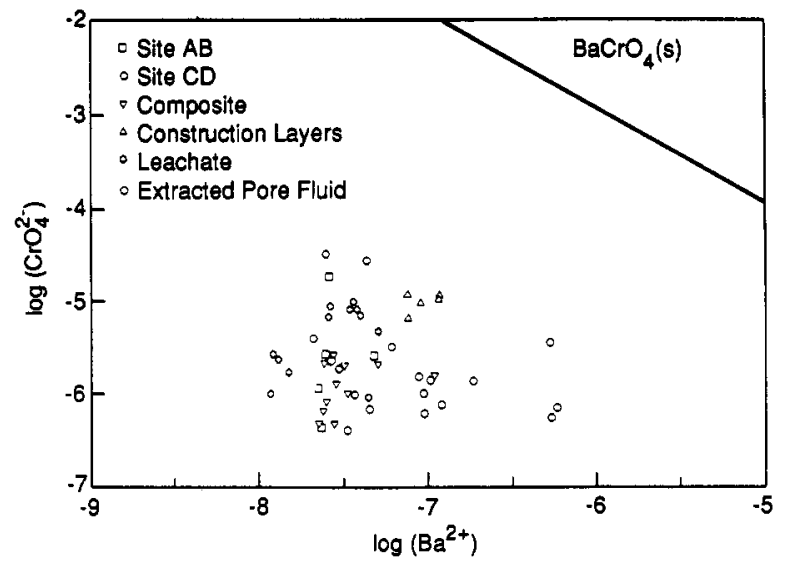

Figure 7. Plot of calculated $\log \mathrm{CrO}_{4}{ }^{2-}$ activity vs calculated $\log \mathrm{Ba}^{2+}$ activity for various fly ash lysimeter samples, compared to activities predicted (solid line) from control by $\mathrm{BaCrO}_{4}(\mathrm{~s})$.

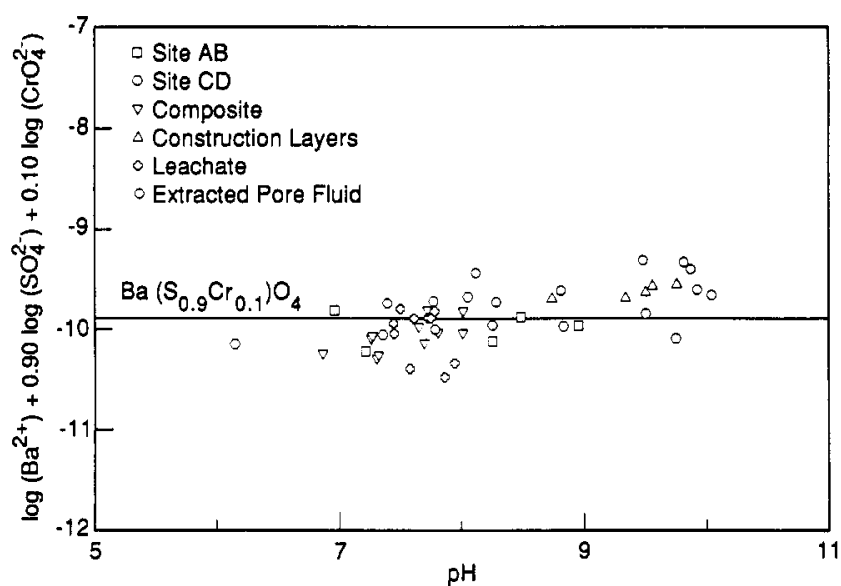

Flgure 8. Plot of $\left[\log \left(\mathrm{Ba}^{2+}\right)+0.9 \log \left(\mathrm{SO}_{4}{ }^{2-}\right)+0.1 \log \left(\mathrm{CrO}_{4}{ }^{2-}\right)\right]$ vs $\mathrm{pH}$ observed in different solutions. The solid line is based on activities in equilibrium with $\mathrm{Ba}\left(\mathrm{S}_{0.9} \mathrm{Cr}_{0.1}\right) \mathrm{O}_{4}$ reported by Rai et al. (25).

Figure 8 shows a $\mathrm{Ba}(\mathrm{S}, \mathrm{Cr}) \mathrm{O}_{4}$ solid solution that, if present, could be controlling the chromate concentrations. The various aqueous analyses could be fit by solid-solution composition of $\mathrm{Ba}\left(\mathrm{S}_{0.9} \mathrm{Cr}_{0.1}\right) \mathrm{O}_{4}$. Whether this solid solution in fact controlled the aqueous $\mathrm{Cr}$ (VI) concentrations in Montour samples could not be definitely assessed with this set of data. The $\mathrm{Ba}\left(\mathrm{S}_{0.9} \mathrm{Cr}_{0.1}\right) \mathrm{O}_{4}$ solid solution is a plausible solubility control because the large variability in $\mathrm{Cr}(\mathrm{VI})$ concentrations as a function of depth, time, and $\mathrm{pH}$ is well explained by this single hypothesized solid phase (Figure 8). There was also enough $\mathrm{Ba}, \mathrm{Cr}$, and $\mathrm{SO}_{4}{ }^{2-}$ present in the ash that $\mathrm{Ba}\left(\mathrm{S}_{0.9} \mathrm{Cr}_{0.1}\right) \mathrm{O}_{4}$ could form.

One study of fly ash disposal in a marine environment showed the $\mathrm{Cr}$ to be present in that system largely as $\mathrm{Cr}$ (III) (26). Studies have shown (25) that $\mathrm{Cr}$ (III) in fly ash systems generally forms solid solutions with iron hydroxides $\left[(\mathrm{Fe}, \mathrm{Cr})\left(\mathrm{OH}_{3}\right)\right]$. These solid solutions show very low solubilities $\left(<10^{-7} \mathrm{M}\right)$ at the $\mathrm{pH}$ levels of the samples used in this study. Therefore, very low leachate $\mathrm{Cr}$ concentrations can be expected in those fly ash systems where $\mathrm{Cr}$ (III) is the major redox species.

Copper. Detectable aqueous $\mathrm{Cu}$ concentrations were observed in the pore-water sampler nest composite samples, the construction-layer samples, and pore waters from the ash cores. Tenorite $(\mathrm{CuO})$ and malachite $\left[\mathrm{Cu}_{2} \mathrm{O}\right.$ $\mathrm{H})_{2} \mathrm{CO}_{3}$ ] have been predicted to be present in fly ash samples $(20,27)$. It has been reported (10) that under oxidizing conditions, like those present in the field lysimeter, and in the $\mathrm{pH}$ range measured at the test cell, $\mathrm{CuO}$ is the most likely solubility-controlling phase among the

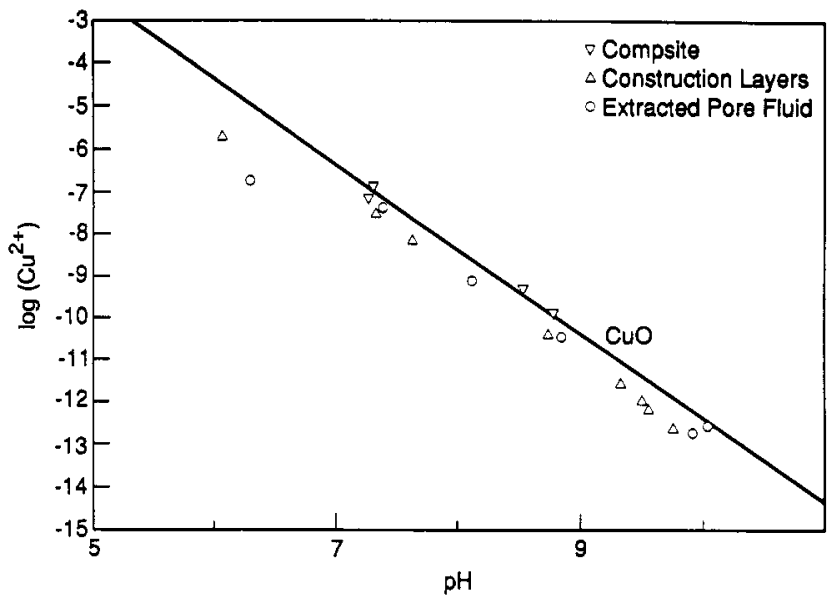

Flgure 9. Plot of calculated $\log \mathrm{Cu}^{2+}$ activity vs $\mathrm{pH}$ for various fly ash lysimeter samples, compared to activities predicted (solid line) from control by CuO (tenorite).

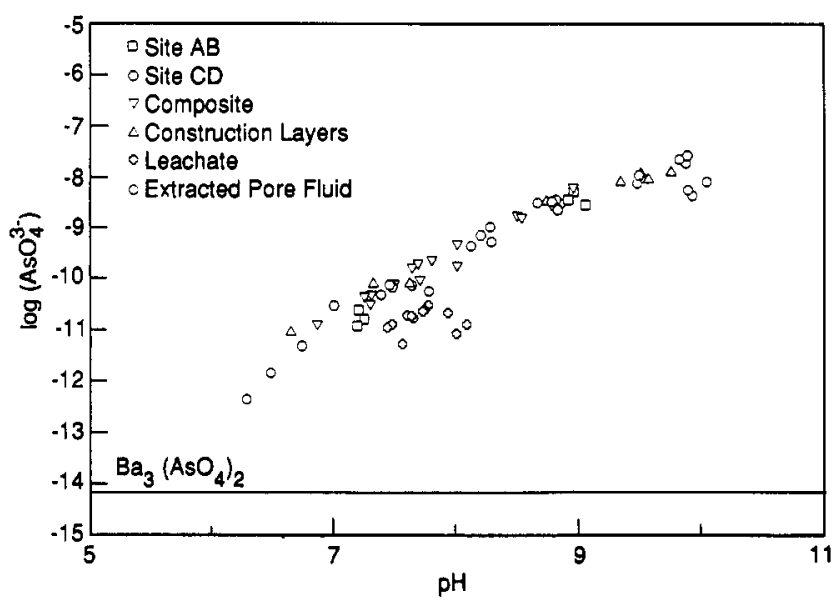

Figure 10. Plot of calculated log $\mathrm{AsO}_{4}{ }^{3-}$ activity vs $\mathrm{pH}$ for various fly ash lysimeter samples, compared to acthities predicted (solld line) from control by $\mathrm{Ba}_{3}\left(\mathrm{AsO}_{4}\right)_{2}$ when $\mathrm{Ba}^{2+}$ is fixed at $10^{-7.5} \mathrm{M}$.

solids that may be present in near-surface geologic environments [the others are $\mathrm{Cu}_{4} \mathrm{SO}_{4}(\mathrm{OH})_{6}, \mathrm{Cu}_{2}(\mathrm{OH})_{2} \mathrm{CO}_{3}$, and $\mathrm{Cu}(\mathrm{OH})_{2}$. $\mathrm{CuO}$ has also been reported as a common ore mineral in oxidized systems (23). These findings, along with the fact that measured $\mathrm{Cu}^{2+}$ activities are similar to those predicted from $\mathrm{CuO}$ (Figure 9), indicate that the aqueous $\mathrm{Cu}$ concentrations in the field lysimeter samples were controlled by $\mathrm{CuO}$ (tenorite). Our extensive laboratory studies (unpublished results) with four different fly ashes that were equilibrated at different $\mathrm{pH}$ values with and without the addition of $\mathrm{CuO}$ and $\mathrm{Cu}^{2+}$ also indicate that $\mathrm{CuO}$ is the solubility-controlling solid.

Other Trace Elements. In addition to the elements discussed above, aqueous concentrations of several other trace elements (As, B, Cd, Mo, and Se) were also measured. Using the existing thermochemical data, attempts were made to determine whether their concentrations could be related to precipitation/dissolution reactions. These attempts were unsuccessful. Therefore, it was not clear whether the aqueous concentrations of these elements were controlled by precipitation/dissolution, adsorption/desorption, or rates of dissolution of fly ash matrix.

Calculations using the standard redox potentials for $\mathrm{As}(\mathrm{III})$ and $\mathrm{As}(\mathrm{V})$ suggested that As should be in the As(V) state at the Eh levels found in the test cell solutions. Speciation measurements have not been performed to test this hypothesis. Barium arsenate $\left[\mathrm{Ba}_{3}\left(\mathrm{AsO}_{4}\right)_{2}\right]$ has been proposed as a solubility-controlling phase for $\mathrm{As}(\mathrm{V})(28)$. However, the plots of $\mathrm{AsO}_{4}{ }^{3-}$ activity against $\mathrm{pH}$ in Figure 
Table III. Summary of Inferred Solubility-Controlling Solids

solubility-controlling solid

\begin{tabular}{|c|c|c|}
\hline element & formula & name \\
\hline $\mathrm{Al}$ & $\mathrm{Al}(\mathrm{OH})_{3}(\mathrm{am})(\mathrm{pH} 6-9)$ & $\begin{array}{l}\text { amorphous aluminum } \\
\text { hydroxide }\end{array}$ \\
\hline $\begin{array}{l}\mathrm{Fe} \\
\mathrm{Ca}, \mathrm{S} \\
\mathrm{Ba}, \mathrm{Sr}\end{array}$ & $\begin{array}{l}\mathrm{Al}(\mathrm{OH})_{3}(\mathrm{c})(\mathrm{pH}>9) \\
\mathrm{Fe}(\mathrm{OH})_{3}(\mathrm{am}) \\
\mathrm{CaSO}_{4} \cdot 2 \mathrm{H}_{2} \mathrm{O} \\
(\mathrm{Ba}, \mathrm{Sr}) \mathrm{SO}_{4}\end{array}$ & $\begin{array}{l}\text { gibbsite } \\
\text { amorphous ferric hydroxide } \\
\text { gypsum } \\
\text { barium and strontium } \\
\text { coprecipitates }\end{array}$ \\
\hline $\mathrm{Cu}$ & $\mathrm{CuO}(\mathrm{c})$ & tenorite \\
\hline $\mathrm{Cr}$ & $\mathrm{Ba}(\mathrm{S}, \mathrm{Cr}) \mathrm{O}_{4}$ & $\begin{array}{l}\text { barium sulfate/barium } \\
\text { chromate solid solution }\end{array}$ \\
\hline
\end{tabular}

10 do not appear to support that hypothesis for these samples. Similar results were reported by another study (29).

No conclusive statements regarding the mechanisms that control $\mathrm{Cd}$ behavior can be made. The observed aqueous concentrations of $\mathrm{Cd}$ were near their detection limits and were similar to those reported in a previous study of a large number of fly ashes (5).

Measured B, Mo, and Se concentrations were well above detection limits, varied widely, and were essentially independent of $\mathrm{pH}$. The estimated thermochemical data for several borate minerals (pinnoite, inderite, inyoite, colemanite, inderborite, hungchaoite, borax, sborgite, McAllisterite, kaliborite, and nobleite) has shown that these $B$ minerals are very soluble and could not control B concentrations in the field lysimeter $(30)$. The observed $B$ concentrations fell within the range of values for $B$ reported for a large number of fly ash extracts (5). In the case of $\mathrm{Mo}$, powellite $\left(\mathrm{CaMoO}_{4}\right)$ appears to control $\mathrm{Mo}$ concentrations in hot-water extracts of many fly ashes (5). However, the observed activities of $\mathrm{MoO}_{4}{ }^{2-}$ in the large field lysimeter samples were about an order of magnitude higher than the activities in equilibrium with $\mathrm{CaMoO}_{4}$, suggesting that $\mathrm{CaMoO}_{4}$ was not the solubility-controlling solid. The mechanisms that may control B, Mo, and Se concentrations are not understood.

Summary of Results. Collectively, these results in. dicate that the observed aqueous concentrations of $\mathrm{Al}, \mathrm{Ba}$, $\mathrm{Ca}, \mathrm{Cr}, \mathrm{Cu}, \mathrm{Fe}, \mathrm{S}, \mathrm{Si}$, and $\mathrm{Sr}$ were controlled by solubility phenomena. Regardless of the origin of the aqueous samples (i.e., their location, depth, and when they were taken at the large field lysimeter site), the aqueous concentrations of these elements in all of these samples were explained by specific solubility reactions. The solubility-controlling solids for different elements are listed in Table III. To draw definite conclusions regarding these inferred solid phases, further experiments must demonstrate their existence. Plausible geochemical reactions that could control the aqueous concentrations of $\mathrm{As}, \mathrm{B}, \mathrm{Cd}, \mathrm{Mo}$, and Se were not identified.

\section{Discussion}

The solubility controls identified in this paper for various elements were based on matching calculated single ion activities for elements with activities expected in equilibrium with different solid phases. Such evidence is by its nature circumstantial. Therefore, this type of analysis should be considered as a guide to further experimentation to confirm the presence of these solid phases, rather than as a definitive proof. This confirmation can be done by either direct or indirect methods. Direct methods include X-ray diffraction and various electron spectroscopies. Indirect methods include observing the
$\mathrm{pH}$ behavior of the element over a wider $\mathrm{pH}$ range or approaching equilibrium for the proposed solid in the sample from both oversaturation and undersaturation. In most cases, indirect methods will be most applicable because trace-element solids are present in low concentrations.

Hypothesized reactions pertaining to the solubilitycontrolling solids have been discussed in the previous section. In inferring that the concentrations of several elements (e.g., $\mathrm{Al}, \mathrm{Ba}, \mathrm{Ca}, \mathrm{Cu}, \mathrm{Fe}, \mathrm{S}, \mathrm{Sr}$ ) are controlled by solubility limits, it was assumed that the observed elemental concentrations were governed by equilibrium reactions and that the solubility-controlling solids were present in the ash. Before the conclusions can be relied upon, the validity of these assumptions must be ascertained.

Most of the solubility-controlling solids expected to be present in the Montour ash are sulfate and hydroxide compounds (Table III), which are known to have rapid precipitation/dissolution kinetics. Most environmentally important aqueous complexation reactions that would affect the final concentrations in equilibrium with solubility-controlling solids are also rapid. Therefore, it is reasonable to hypothesize that equilibrium reactions control the aqueous concentrations of elements contained in sulfate and hydroxide compounds. The validity of this equilibrium assumption was tested through laboratory batch equilibration experiments of the construction-layer samples. As can be seen by examination of Figures 1-10, solubility reactions that controlled aqueous concentrations in the lysimeter pore waters developed in the laboratory in 7 days or less.

\section{Conclusions}

A variety of solid and aqueous samples from a large field lysimeter site were analyzed, and the resulting data were modeled by using an equilibrium geochemical code (MINTEQ). Despite the caveats discussed in the preceding section, several conclusions are supported by the results of these studies.

The concentrations of $\mathrm{Al}, \mathrm{Fe}, \mathrm{Cu}, \mathrm{S}, \mathrm{Ba}, \mathrm{Sr}, \mathrm{Cu}$, and $\mathrm{Cr}$ appear to be determined by solubility-controlling solids. Solid solutions appear to play an important role in controlling the concentrations of $\mathrm{Ba}, \mathrm{Cr}$, and $\mathrm{Sr}$. Geochemical reactions controlling the aqueous concentrations of $\mathrm{As}, \mathrm{B}$, $\mathrm{Cd}, \mathrm{Mo}$, and Se were not identified. For elements for which a solubility control is hypothesized, the different types of aqueous samples all show similar activity relationships, regardless of location, depth, time of sampling, or equilibration time.

Registry No. Al, 7429-90-5; As, 7440-38-2; B, 7440-42-8; Ba, 7440-39-3; Zn, 7440-66-6; Ca, 7440-70-2; Cl, 7782-50-5; Cr, 744047-3; Cd, 7440-43-9; Cu, 7440-50-8; F, 7782-41-4; Fe, 7439-89-6; $\mathrm{K}, 7440-09-7 ; \mathrm{Mg}$, 7439-95-4; Mn, 7439-96-5; Mo, 7439-98-7; Na, 7440-23-5; Se, 7782-49-2; Si, 7440-21-3; Sr, 7440-24-6.

\section{Literature Cited}

(1) Murarka, I. P.; McIntosh, D. A. Solid Waste Environmental Studies (SWES): Description, Status, and Available Results; EPRI EA-5322-SR; Electric Power Research Institute: Palo Alto, CA, 1987.

(2) Warren, C. J.; Dudas, M. J. J. Environ. Qual. 1984, 13, $530-538$.

(3) Theis, T. L.; Wirth, J. L. Environ. Sci. Technol. 1977, 11, 1096-1100.

(4) Roy, W. R.; Griffin, R. A.; Dickerson, D. R.; Schuller, R. M. Environ. Sci. Technol. 1984, 18, 734-739.

(5) Ainsworth, C. C.; Rai, D. Chemical Characterization of Fossil Fuel Wastes; EPRI EA-5321; Electric Power Re- 
search Institute: Palo Alto, CA, 1987.

(6) Warren, C. J.; Dudas, M. J. J. Environ. Qual. 1985, 14, 405-410.

(7) Bauer, C. F.; Natusch, D. F. S. Environ. Sci. Technol. 1981, $15,783-788$.

(8) Hansen, L. D.; Silberman, D.; Fisher, G. L. Environ. Sci. Technol. 1981, 15, 1057-1062.

(9) Mattigod, S. V.; Ervin, J. O. Fuel 1983, 62, 927-931.

(10) Rai, Dhanpat; Ainsworth, C. C.; Eary, L. E.; Mattigod, S. V.; Jackson, D. R. Inorganic and Organic Constituents in Fossil Fuel Combustion Residues. A Critical Review; EPRI EA-5176; Electric Power Research Institute: Palo Alto, CA, 1987; Vol. 1.

(11) Theis, T. L.; Richter, R. O. Environ. Sci. Technol. 1979, 13, 219-224.

(12) Groenewald, G. H.; Hassett, D. J.; Koob, R. D.; Manz, O. E. In Fly Ash and Coal Conversion By-Products: Characterization, Utilization and Disposal I; McCarthy, G. J., Lauf, R. J., Eds.; Materials Research Society: Pittsburgh, PA, 1985; Vol. 43, pp 213-226.

(13) Villaume, J. F.; Bell, J. W.; LaBuz, L. L. In Fly Ash and Coal Conversion By-Products: Characterization, Utilization and Disposal IV; McCarthy, G. J., Glasser, F. P., Roy, D. M., Hemmings, R. T., Eds.; Materials Research Society: Pittsburgh, PA, 1988; Vol. 133, pp 325-332.

(14) Rehm, B. W.; Christel, B. J.; Stolzenburg, T. R.; Nichols, D. G. Field Evaluation of Instruments for the Measurement of Unsaturated Hydraulic Properties of Fly Ash; EPRI EA-5011; Electric Power Research Institute: Palo Alto, CA, 1987.

(15) Kinniburgh, D. G.; Miles, D. L. Environ. Sci. Technol. 1983 , $17,362-368$

(16) Felmy, A. R.; Girvin, D. C.; Jenne, E. A. MINTEQ-A Computer Program for Calculating Aqueous Geochemical Equilibria; EPA 600/3/84/032; U.S. Environmental Protection Agency, Office of Research and Development: Athens, GA, 1984.

(17) Brown, D. S.; Allison, J. D. MINTEQ A1, An Equilibrium Metal Speciation Model: User's Manual; EPA 600/387/012; U.S. Environmental Protection Agency, Athens Environmental Research Laboratory: Athens, GA, 1987.
(18) Peterson, S. R.; Hostetler, C. J.; Deutsch, W. J.; Cowan, C. E. MINTEQ User's Manual; NUREG/CR-4808 (PNL6101); U.S. Nuclear Regulatory Commission: Washington, DC, 1987.

(19) Roy, W. R.; Griffin, R. A. Environ. Sci. Technol. 1984, 18, 739-742.

(20) Talbot, R. W.; Anderson, M. A.; Andren, A. W. Environ. Sci. Technol. 1978, 12, 1056-1062.

(21) Simons, H. S.; Jeffery, J. W. J. Appl. Chem. 1960, 10, 328-336.

(22) Scheetz, B. E.; White, W. B. In Fly Ash and Coal Conversion By-Products: Characterization, Utilization, and Disposal I; McCarthy, G. J., Lauf, R. J., Eds.; Materials Research Society: Pittsburgh, PA, 1985; Vol. 43, pp 53-60.

(23) Mason, B.; Berry, L. G. Elements of Mineralogy; W. H. Freeman \& Co.: New York, 1968.

(24) Zachara, J. M.; Girvin, D. C.; Schmidt, R. L.; Resch, C. T. Environ. Sci. Technol. 1987, 21, 589-594.

(25) Rai, D.; Zachara, J. M.; Eary, L. E.; Ainsworth, C. C.; Amonette, J. E.; Cowan, C. E.; Szelmeczka, R. W.; Resch, C. T.; Schmidt, R. L.; Girvin, D. C.; Smith, S. C. Chromium Reactions in Geologic Materials; EPRI EA-5741; Electric Power Research Institute: Palo Alto, CA, 1988.

(26) Hjelmar, O. In Proceedings of the International Conference on Coal Fired Power Plants and the Aquatic Environment Copenhagen, Denmark; International Association of Water Pollution Research: London, 1982.

(27) Theis, T. L.; Halvorsen, M.; Levein, A.; Stankunas, A.; Unites, D. Fly Ash Leachate Attenuation Mechanisms. Draft report; TRC Environmental Consultants, Inc: East Hartford, CN, 1982.

(28) Wageman, R. Water Res. 1978, 12, 139-145.

(29) Turner, R. R. Environ. Sci. Technol. 1981, 15, 1062-1066.

(30) Mattigod, S. V. Soil Sci. Soc. Am. J. 1983, 47, 654-655.

Received for review October 31, 1989. Accepted March 19, 1990 We gratefully acknowledge the Pennsylvania Power and Light Co. for their cooperation and assistance throughout this project. The research was funded by the Electric Power Research Institute, Inc. (EPRI) under Contract RP2485-08, "Leaching Chemistry".

\section{Determination of Polycyclic Aromatic Hydrocarbons in Urban Street Dusts and Their Source Materials by Capillary Gas Chromatography}

\section{Hideshige Takada, " Tomoko Onda, and Norio Ogura}

Department of Environmental Science and Conservation, Faculty of Agriculture, Tokyo University of Agriculture and Technology, Fuchu, Tokyo 183, Japan

- Molecular distributions of polycyclic aromatic hydrocarbons (PAHs) in street dust samples collected from the Tokyo metropolitan area were determined by capillary gas chromatography following HPLC fractionation. Sixty-four compounds including three- to six-ring PAHs and sulfur heterocyclics were identified by capillary GC/MS. Total $\mathrm{PAH}$ concentrations were in the range of a few micrograms per gram of dust. The source materials (automobile exhaust, asphalt, fuel-oil combustion products) were also analyzed. The PAH profile, especially relative abundance of alkyl-PAHs and sulfur-containing heterocyclics, indicated that PAHs in the street dusts on the heavily trafficked streets are strongly affected by automobile exhausts and those in the residential area have a somewhat more significant contribution from combustion products in stationary sources. With both types of dusts, asphalt is thought to contribute only a minor part of their PAHs.

Introduction

Polycyclic aromatic hydrocarbons (PAHs) have long been recognized as hazardous environmental chemicals.
Some PAHs are known to be carcinogenic to man (1). PAHs are mainly formed during the combustion of coal and petroleum (2) and are widely distributed in soils and sediments throughout the world (3-9). Their sources and transport mechanisms have been the subject of a number of recent investigations $(10-19)$. On urban street surfaces, PAHs of various origins (e.g., weathered materials of street surfaces, automobile exhaust, lubricating oils, gasoline, diesel fuel, tire particles, and atmospherically deposited materials) are present as street dust. The street dust material is washed from roads during heavy rain storms and transported to rivers, wastewater treatment plants, and estuaries $(17,18)$. Therefore, street dust is considered to be one of the important sources of PAHs in the aquatic environment, but the data available on PAHs in street dusts are limited $(14,20,21)$. In particular, their detailed molecular compositions were rarely given $(14,20)$, although $\mathrm{PAH}$ profiles are useful to estimate their sources and fates. For example, Wakeham et al. (14) extensively characterized PAH profiles for lacstrine sediments, street dust, and plausible source materials (asphalt, automobile exhaust, 